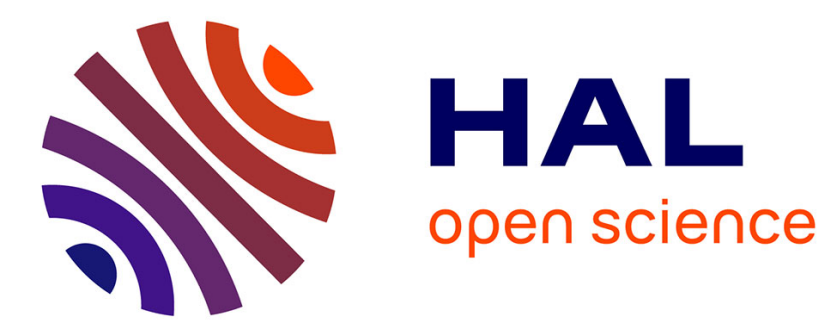

\title{
Epiphanic Reading in Ann Radcliffe's The Mysteries of Udolpho
}

Thomas Dutoit

\section{To cite this version:}

Thomas Dutoit. Epiphanic Reading in Ann Radcliffe's The Mysteries of Udolpho. Wim Tigges. Moments of Moment. Aspects of the Literary Epiphany, 25, Rodopi, pp.85-100, 1999, Studies in Literature, 90-420-0636-6. hal-01163536

\section{HAL Id: hal-01163536 https://hal.univ-lille.fr/hal-01163536}

Submitted on 16 Oct 2017

HAL is a multi-disciplinary open access archive for the deposit and dissemination of scientific research documents, whether they are published or not. The documents may come from teaching and research institutions in France or abroad, or from public or private research centers.
L'archive ouverte pluridisciplinaire HAL, est destinée au dépôt et à la diffusion de documents scientifiques de niveau recherche, publiés ou non, émanant des établissements d'enseignement et de recherche français ou étrangers, des laboratoires publics ou privés. 
Moments

of Moment

Aspects of

the Literary

Epiphany

Edited by Wim Tigges

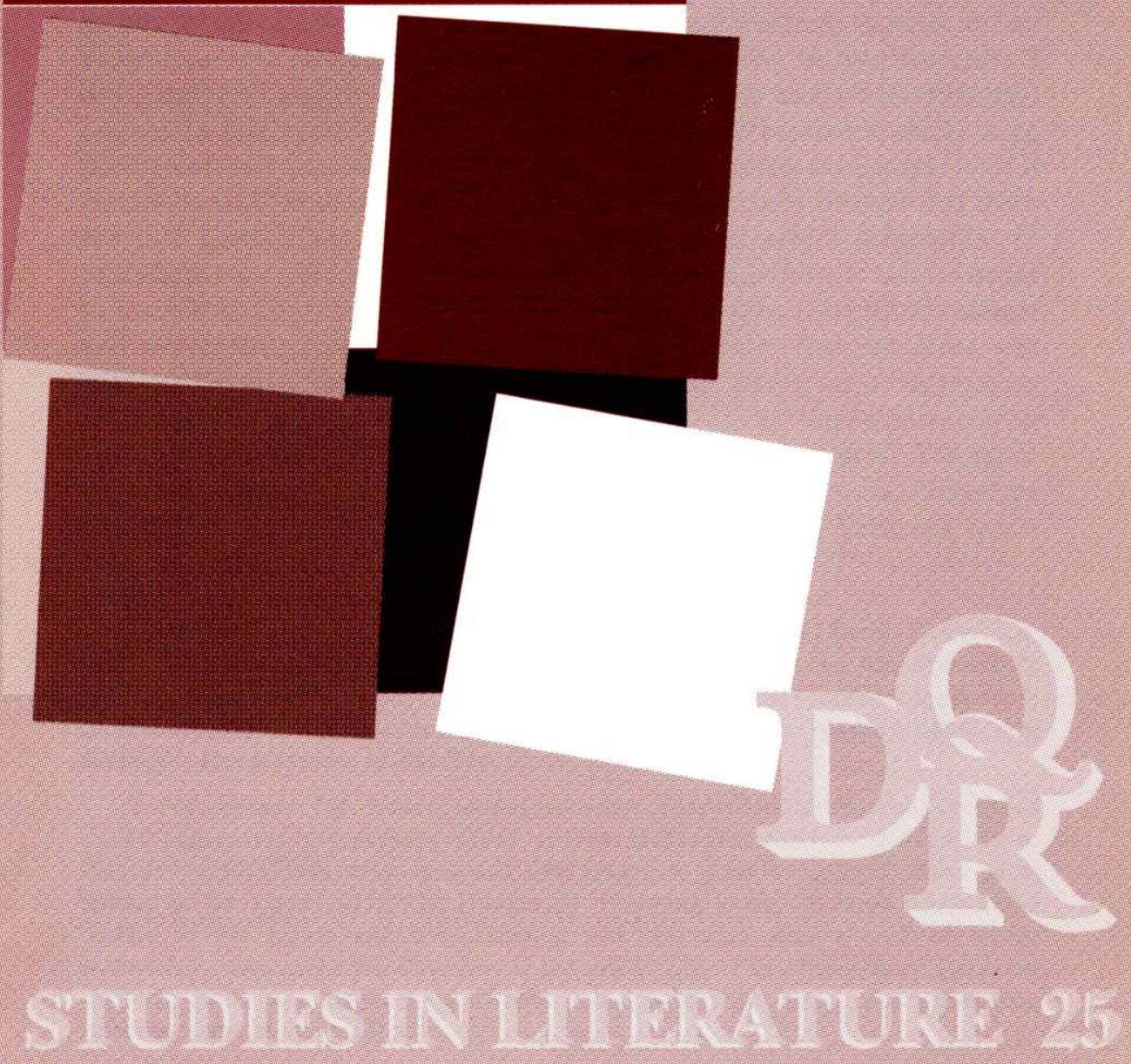




\section{EPIPHANIC READING IN ANN RADCLIFFE'S \\ THE MYSTERIES OF UDOLPHO}

\section{THOMAS DUTOIT}

An epiphany, from the Greek epiphaneia, appearance, has to do with vision: it is a revelatory manifestation of a divine being or a spiritual event in which the essence of a given object of manifestation appears to the subject, as in a sudden flash of recognition. Epiphany in Ann Radcliffe's Mysteries of Udolpho is related to one of the two kinds of vision that coexist in this text. Vision, in this properly picturesque romance, is of such a colossal importance and has been so abundantly discussed, ${ }^{1}$ that it cannot be tackled in its entirety here. May it summarily be said that there are two basic kinds of vision. One is a detailed visual description of landscape which entails prior education, instruction in how to see, in order to be able to appreciate, and even notice what is seen (beautiful, sublime and picturesque views according to Claude Lorrain, Salvator Rosa and William Gilpin). Such vision is a learned reading. There are a fair number of passages where Emily is taught - by St Aubert, by Valancourt - how to see, i.e., read a landscape so as to be able to appreciate it. ${ }^{2}$ The other kind of vision is not a reading; it is more properly a foreclosed or interrupted vision, frequently conceptualized as "terror". Terrified vision

1. On the Radcliffean picturesque, may it suffice to refer to Charles Kostelnick, "From Picturesque View to Picturesque Vision: William Gilpin and Ann Radcliffe", Mosaic, XVIII (1989), 31-48; Chloe Chard, "Introduction" and "Explanatory Notes", in Ann Radcliffe, The Romance of the Forest, Oxford, 1986; Maurice Lévy, Ann Radcliffe: The Mysteries of Udolpho, Paris, 1996.

2. For instance: "St. Aubert pointed out to her observation the course of the rivers ... the boundaries of provinces, which science, rather than the eye, enabled him to describe" (29); "Valancourt now and then spoke, to point to Emily's notice some feature of the scene" (43); "he [Valancourt] pointing to her attention some grand feature of the scene; and she, listening and observing with a look of tender seriousness, that spoke the elevation of her mind" (49); The Mysteries of Udolpho, Oxford, 1981. All emphases are mine unless otherwise noted. All subsequent references are to this edition. 
is always a vision of that which paradoxically cannot be seen, described or transcribed in language. It is therefore always the vision according to which there would be something not belonging to the visible order of things. ${ }^{3}$

The first kind of vision may seem to be epiphanic, because associated with God, but it is not, since it only involves "thoughts" that "rise" to God: it always involves a thinking of a concept of God and not any vision of God: ${ }^{4}$ It is thus purely abstract, and moreover taught: it is thus transmissible and has nothing to do with a "sudden recognition". This paper will focus rather on the other kind of vision, foreclosed and epiphanic vision insofar as it functions as the paradoxical manifestation of that which does not belong to the visible order of things. Epiphany, in The Mysteries of Udolpho, is seeing what one ought not to see, what one in fact does not or cannot see, or what is not really there. What is seen but does not belong to the visible order of things is of a ghostly, spiritual or phantomesque nature. Furthermore, such epiphany is especially linked to seeing what one should not read, to reading what one should not see. This paper will focus on Emily's epiphanies - the moments when she seems to see the ghost of her father - moments which occur precisely when she sees what she is not supposed to read, in order to investigate the nature of the epiphany and its relation to reading. Emily's epiphanies thus raise the question: how is seeing different from reading, how does reading involve not seeing? In particular, given that Emily is, as we will see, positioned as a reader (akin to the reader relative to the book itself), how do the epiphanies experienced by Emily create the epiphanies experienced by the reader of Radcliffe's romance? In short, how does epiphany at the plot level - the seeing, on account of a desire to read, ghosts that are not there - rhyme with epiphany at the level of the reader of the Gothic romance - seeing/reading, on account of an alertness to puns, meanings which "should" not be there?

3. "Terror" is how Radcliffe translated Edmund Burke's notion of the "sublime" into her fiction. Radcliffe provided a theoretical account of this translation in her "On the Supernatural in Poetry", New Monthly Magazine, XVI (1826): 145-52; cf Maurice Lévy, "A Propos des Mystères d'Udolphe: Ann Radcliffe et la poétique du cachén, Etudes Anglaises, XLIX/4 (1996): 402-12. Radcliffe's aesthetic of "terror", Burke's of the "sublime", present the paradox that there would be an unpresentable, an epiphanically momentary glancing of that which must remain hidden from representation.

4. "... her thoughts rose, as before, towards the sublimity of the Deity" (72; cf. $6,28,36,47)$.
Epiphany as the appearing alive of the inanimate and the becoming inanimate of the living

The main epiphanic scene, in which Emily seems to see her father's ghost, takes place when she follows, after his death, his death-bed injunction to burn the papers he has left in the closet of his room. The epiphany does not, however, simply consist in Emily seeing a ghost. Whereas it is said, of a moment earlier in the novel when St Aubert was alive, that Emily "had seen her father sit [in the same room] ... looking over, with so much emotion, ... these very papers" (102), at the moment when Emily is about to obey the dead man's instructions, it is clearly stipulated that she does not see. Indeed, as she enters the room, her eyes are autonomous, detached from her mind, as they scan erratically the room: "her eyes glancing a second time on the arm-chair" (102). In this moment of epiphany, it is not Emily who sees someone or something: the text does not continue by saying, as we might expect, "she saw ...", making her the active agent of seeing. Rather, the text continues by making the dead father, who appears to her, be the active agent: as she enters the room, after "glancing" on the arm-chair and before finding the papers, "the countenance of her dead father appeared there" (103). Furthermore, a second time, after she pulls the papers out of the closet, "on looking up, there appeared to her alarmed fancy the same countenance in the chair" (103). She thus does not see something; rather, something - "the countenance of her dead father" - appears to her.

This reversal of the active agent, from the living to the dead, is reinforced by the very status of the arm-chair: "the arm-chair ... stood in an obscure part of the closet" (102), and "Emily stood fixed for a moment to the floor" (103). The "arm-chair" is standing, and thus has what one catachretically calls "legs" or "feet". Already the "chair", called first a "great chair", has what are also catechretically called "arms" (an "armchair"). Coupled with the fact that "the countenance of her dead father appeared there", the "chair" has not only legs upon which it stands and "arms", but also a face. It is thus no stretch of the readerly imagination to see in the word "chair" itself that which fleshes out this appearance, namely its chair or, as this French word indicates, its "flesh". This word "chair" can be taken even farther, once we read closely how Emily "readily" found the concealed "bundle" and "purse" of her father, for then we will see the appearance of this word "chair" as the vulgar slang pun that it was in Radcliffe's time, namely, the male genitalia. ${ }^{5}$ The "chair" is thus already a first element that points to a nexus linking

5. See Slang of Venery and its Analogues, Chicago, 1916, "chair". 
epiphany and sexuality. If the "chair" becomes more than animated, Emily becomes a sort of chair or piece of furniture: "Emily stood fixed ... to the floor", screwed to the floor like unmoveable room furniture. Not only inanimate, Emily is as if dead, and after that ghostly: she "stood fixed for a moment to the floor, after which she left the closet. Her spirits, however, soon returned". Moving like a spiritless body, it is in terms of "spirits" that her return to reason is presented: "Her spirits, however soon returned; she reproached herself". "She" does not exist until after her spirits (and not "she") return to her body. Epiphany thus takes place as a becoming inanimate of the living, and a becoming alive of the inanimate.

This epiphanic moment, when her father's ghost appears to Emily who is about to burn his papers, is prefigured by a previous scene in the novel, at the end of the second chapter, when Emily discovers her father hunched over mysterious papers and prostrate before a picture of a woman not his wife. This picture and these papers (as well as other clues strewn throughout the book) lead Emily to believe that her father is in love with another woman. Indeed:

... she saw him seated at a small table, with papers before him, some of which he was reading with deep attention and interest, during which he often wept, and sobbed aloud .... [She] conclud[ed] that those papers were letters of her late mother ... ... she saw him turn again to the papers. He took from among them a small case, and from thence a miniature picture. The rays of light fell strongly upon it, and she perceived it to be that of a lady, but not of her mother.

St Aubert gazed earnestly and tenderly upon this portrait, put it to his lips, and then to his heart, and sighed with a convulsive force. Emily could scarcely believe what she saw to be real. She never knew till now that he had a picture of any other lady than her mother, much less that he had one which he evidently valued so highly; but having looked repeatedly, to be certain that it was not the resemblance of Madame St Aubert, she became entirely convinced that it was designed for that of some other person (26).

Emily's vision, a vision associated with transgression since Emily is spying on her father, is already suggested as a sort of epiphany insofar as her father appears as a horrible ghost (St Aubert "rose, a ghastly paleness ... on his countenance", with "a look ... which was mingled with a certain wild expression, that partook ... of horror") and insofar as what appears to be another loved woman, author of the letters, makes her apparition under the rays of light. The epiphany here thus takes the form of the living
father appearing as dead.
Epiphanic Reading in Ann Radcliffe's The Mysteries of Udolpho 89

It must be recalled that Emily's vision takes place at a point in the novel when she seems to have secured for herself her mother's place next to her father. Indeed, Emily St Aubert is presented as having symbolically killed her mother, Madame St Aubert, who dies before the end of the first of the fifty-five chapters of the romance. ${ }^{6}$ Emily's symbolic murder of her mother allows her to become the partner of her father, and the reader is thus able to see in the father-daughter relation an incestuous relation. ${ }^{7}$ To some degree, from the second chapter until the seventh chapter when St Aubert dies, Emily and her father form a sort of couple. ${ }^{8}$ It is precisely when Emily and her father are about to embark on what could be called their "honeymoon" - they take a five chapter-long touristic trip through the mountains - that Emily, spying on her father, has the vision of her place having been already superseded by another quasi-phantasmatic woman ("Emily scarcely believed what she saw to be real"), and of St Aubert proleptically transformed into the ghost ("ghastly paleness") he will become when Emily "discloses" the papers and the picture (104). What is more, the apparently unreal other woman will repeatedly be set up as Emily's real incestuous sister/mother, namely St Aubert's sister, the Marchioness.

This scene, in which the father seems to be already a ghost, and the "other" woman comes out of nowhere, is re-written in the main epiphanic scene when Emily performs her father's command to destroy the papers she had seen him read at the end of the second chapter. This main epiphanic scene is introduced by an epigraph, taken from Macbeth, which is also about an epiphany: "Can such things be,/ And overcome us like a summer's cloud,/ Without our special wonder?" (102). The epigraph tells of a sudden, odd and spiritual manifestation. In fact, it tells of seeing a

6. The symbolic murder occurs in Emily's poem, "The Glow-Worm", which she recites alone with her father, both of whom are the "two lovers" who "seek the purple flow' $r$ " and "shun the fairy-queen / Who frowns upon their plighted vows". As if realizing Emily's desire expressed in the poem, Mme St Aubert dies immediately thereafter, so that Emily is "her slave no longer" (17).

7. The matrix of Radcliffe's incest plot is Walpole's text about "muttering" incest called "The Mysterious Mother" (quoted in The Romance of the Forest, 15).

8. One might object that Valancourt, the young man whom Emily will ultimately marry, shares much of the space of these chapters with Emily and her father, and moreover that Valancourt clearly begins courting Emily in a way approved by her father, yet although that is true, Valancourt is nonetheless repeatedly defined by St Aubert himself as a clone or copy of himself (Emily's father). Valancourt's presence does not alter the fact that Emily is presented as having taken the wife's position as lover of the husband. 
ghost: Macbeth has just seen the ghost of Banquo, whom he has had murdered. Macbeth says that were the ghost anything but a ghost, he would "never tremble" and instead attack it. Were the ghost any live beast, Macbeth would not feel like a scared girl:

If trembling I inhabit then, protest me

The baby of a girl. Hence, horrible shadow!

Unreal mockery, hence!

(III. iv. 105-07)

Macbeth has thus had an epiphany, seeing the ghost of Banquo, which no one else present at the table sees. Macbeth is turned into a young girl by the sighting, and Lady Macbeth ridicules him for his belief in a sort of Gothic ghost story avant la lettre:

$\mathrm{O}$, these flaws and starts -

Impostors to true fear - would well become A woman's story at a winter's fire,

Authoriz'd by her grandam.

(III. iv. 63-66)

Macbeth is as it were unmanned by a story told by the likes of "her grandam", Ann Radcliffe, "a woman's story"-teller whom Lady Macbeth would have in fact disqualify his fear. But Lady Macbeth's comparison also transforms Ann Radcliffe into Shakespeare, and makes her protagonist, Emily, a Macbeth-like character in her capacity to see ghosts, to have epiphanies. ${ }^{9}$

Epiphany as disclosing and disclothing the father

After her father's death, Emily enters his bedroom in order to follow the directions he had given her prior to dying: "These papers you must burn-and solemnly I command you, without examining them" (78, Radcliffe's emphasis). She finds the papers without any problem:

By the directions which St Aubert had given her, she readily found the board he had described in an opposite corner of the closet, near the window; she distinguished also the line he had mentioned, and, pressing it as he had bade her, it slid down, and disclosed the bundle of papers, together with some scattered

9. Like the "trembling" "girl" Macbeth before Banquo's ghost, Emily is also "trembling" (102-03) when she enters the "chamber, where St Aubert used to sleep", to "burn the papers" at which moment her father's ghost "appears".

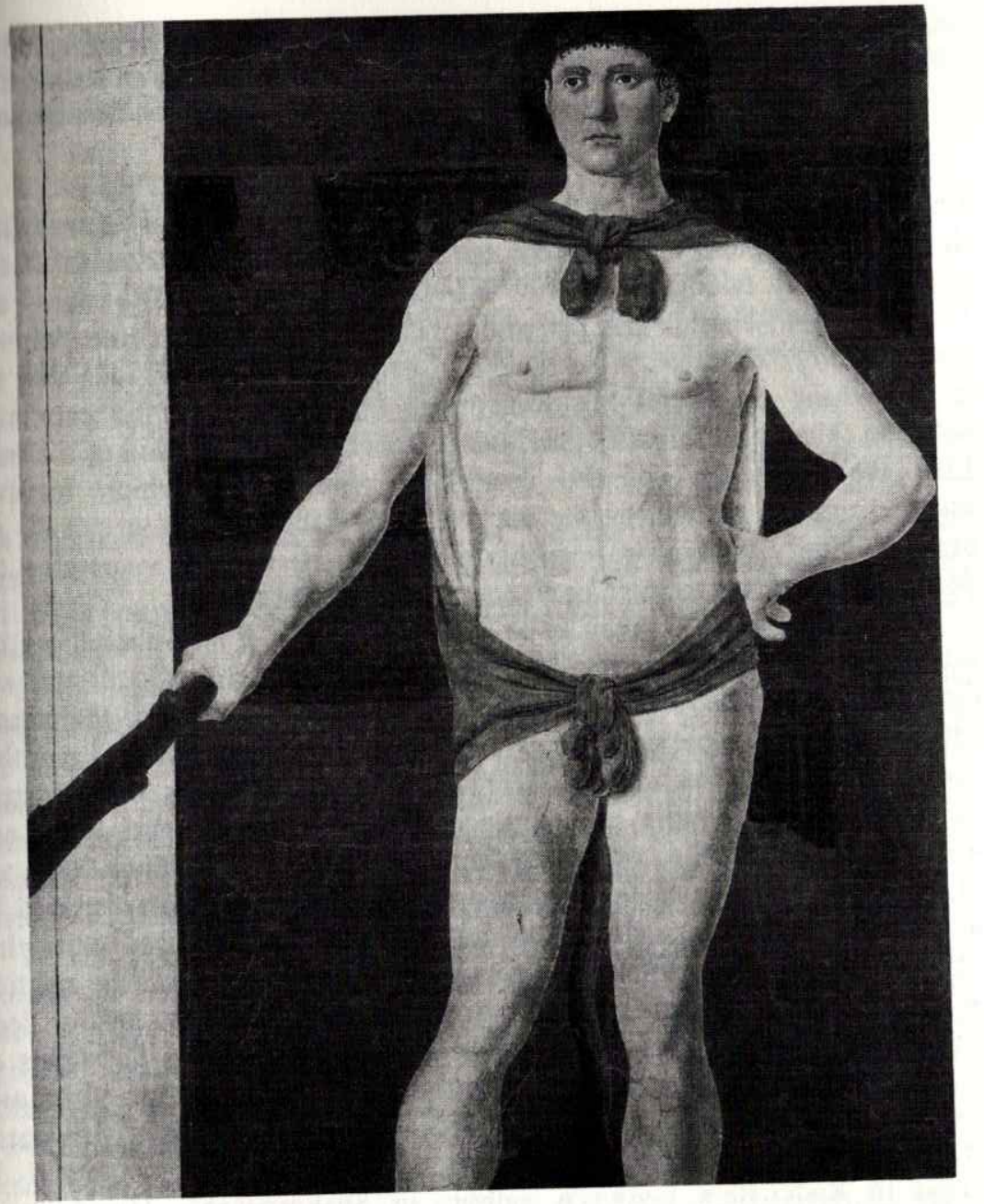

Piero della Francesca Umbrian, Hercules. Fifteenth Century. Fresco in plaster, $151 \times 126 \mathrm{~cm}$. Isabella Stewart Gardner Museum, Boston. 
ones, and the purse of louis. With a trembling hand she removed them, replaced the board, paused a moment, and was rising from the floor, when, on looking up, there appeared to her alarmed fancy the same countenance in the chair (103).

Emily's epiphany of seeing the ghost of her father is that of "disclos[ing] the bundle of papers" taken out of the "closet", which is also that of metaphorically taking his clothes off, dis-clothing him. "Dis-close" and "clothes" both contain the phonemes /kloz/. What's more, the "closet" where Emily "disclosed" the bundle already introduces the idea that she is unclothing or disclothing something, through the phonic proximity between $/ \mathrm{kloz} /$ and $/ \mathrm{kloz}(\mathrm{it}) /$, and because of the very function of a closet. Like the "dressing" of the dead body for burial, which involves uncovering and recovering the corpse, and which no person can do for himself, Emily's taking care of her father's paperwork is something the dead St Aubert has to have someone else do for him.

Moreover, what is given to be glimpsed here is Emily unclothing her father's intimate body parts: "it [the concealing board] slid down, and disclosed the bundle of papers ... and the purse of louis". Both the bundle (of papers) and the purse (of louis) have sexual connotations. ${ }^{10} \mathrm{~A}$ painting such as Piero della Francesca's "Hercules" (see picture) gives an example of bundles. The bundle in the place of his genitals, multiplying and magnifying them while concealing them, is doubled by the knot at the top of his chest, and the relative absence of penis in both is compensated by the tail-like shape descending from his back parts, as well as by the club held in his right hand. Furthermore, as Marc Shell has shown, the relation between the "purse of louis" and scrotum of testicles has a deep history. ${ }^{11}$ A "purse" can mean both what is contained (the "contents of a moneybag") and the container ("moneybag") - or "moneybag and contents taken together" (OED, "purse"). This confusion between purse as container and contained, with contents either monetary or genital, is found in Radcliffe's favourite author, in Shakespeare's Merchant of

10. The narrator recurrently suggests that words may mean more than what they seem to mean. For example, "[Emily] gave a mysterious meaning to [the peasant's] words, such as she had not suspected when he uttered them" (63). The same can be said of the reader's relation to the words of the narrator. The double meaning of the "purse," as both container of money and part of the person (container of testicles), is stressed by the proximity of sounds between "purse" and "person", compounded by the expression "purse of louis": the "louis," by their name, refer to the person of Louis the monarch, whom, as coins, they would probably portray.

11. Marc Shell, Art \& Money, Chicago and London, 1995, 30-37.
Venice. The Christian gentlemen Salario and Solanio tell a story of how Shylock ran through the streets of Venice, after the loss of his supposedly consanguineous child Jessica. Says Solanio:

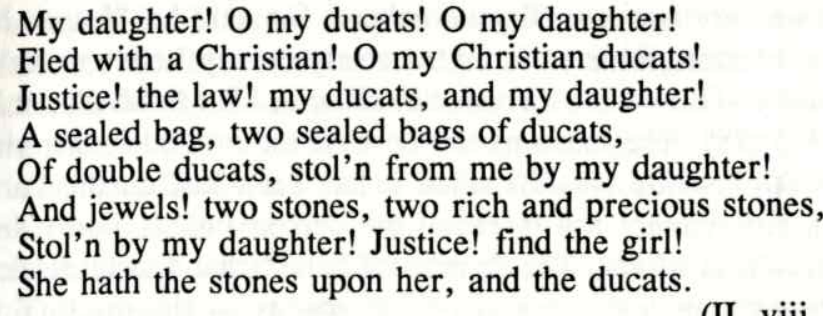

(II. viii. $15-22$ )

The Christian tells the Jew's loss of the "sealed bag", of the "two sealed bags", of his "jewels", his "two stones", as the loss both of his money and of his scrotum, of the double capacity for reproduction (monetary and biological).

If the depiction of Emily "disclosing the bundle and the purse" is that of her undressing her father ("pressing [his clothes] as he bade her, [they] slid down, and disclosed the bundle"), the subsequent depiction of her removal of the "bundle" and the "purse" is that of her lopping off the genitalia of her father: "With a trembling hand she removed them [the "bundle" and the "purse"], [and] replaced the board". The epiphanic moment here thus functions as the daughter's emasculation of her father.

In The Mysteries of Udolpho, the relation between the "purse" and paternity is reinforced by the fact that what the purse contains are "louis d'or". Why "louis d'or"? ? $^{12}$ Throughout Radcliffe's romances, the signifier "Louis" is associated with a lack of fathering capacity and wanted fatherhood. In The Romance of the Forest, Louis de St Pierre is supposed to be the father of Adeline, the Emily-like heroine; similarly, Louis de la Motte, who wants to marry Adeline, is the son of the de la Motte's, who act as foster parents to Adeline; this foster-father figure, de la Motte, gives "solid louis d'ors" to Adeline permitting her escape to freedom. Adeline turns out not to be the daughter of Louis de St Pierre, and in the end she rejects Louis de la Motte. The money and the person named the "louis" are thus associated with would-be fathers and male progenitors. Yet they turn out to be rejected as the father/progenitor, so that the informed reader

12. The "louis d'or" was first minted in 1640 (by Nicholas Briot). Since the action of the romance is set in 1584, their explanation must be other than historical realism. See Shell and R.A.G. Carson, Coins of the World, New York, 1962. 
of The Mysteries of Udolpho is given cause for doubt about St Aubert's fathership when coming upon the "purse of louis" which, moreover, are presented by St Aubert himself as a sign of his failure as father: as he himself repeatedly says, he dies leaving Emily without protection, since the "louis d'or" are not a sufficient fortune for her, he "leaves her poor": "The two hundred louis ... is all the ready money I have to leave you .... I have told you how I am circumstanced with M. Motteville, at Paris. Ah, my child!" (78). The exclamation here of fatherhood is the admission of a failure (to provide wealth) since it has been lost on the Paris bourse; such emission cannot fail to recall the denied fathers Louis de St Pierre and Louis de la Motte. The "purse of louis" that Emily discloses in the closet thus brings about not only the images of the disclothing and the emasculation of the father but also that of a doubtful or failed paternity.

\section{Epiphany and the appearing of the mother}

The disclosure of the papers in the closet, which can be read both as the daughter's emasculation of her father and as what is at stake in the epiphanic appearance of her father's ghost, is itself subtended by the maternal aspect of the "hollow place" in which St Aubert had told Emily she would find the papers (77). Not only are the "bundle of papers" her father has enjoined Emily to burn the same papers she has associated with love letters to and from a woman, but also, after burning the papers, Emily remembers the "purse of louis": "It was long after this [burning the papers], that she recollected the purse". In this purse she perceives "something of a size larger than coin" (104), and she discovers that it contains the picture of a woman: "At the bottom of the purse ... she found $\ldots$ an ivory case, containing the miniature of a - lady!" (104). The lady is immediately identified with the woman over whose picture Emily had seen her father sigh at the end of the second chapter, just before their "honeymoon": "containing the miniature of a - lady! She started - 'The same', said she, 'my father wept over!' On examining the countenance she could recollect no person that it resembled." The lady in turn is identified with the Marchioness: "More than once remembering his manner, when he had spoken of the Marchioness of Villeroi, she felt inclined to believe that this was her resemblance" (104).

Emily has linked her father with the late Marchioness, and the late Marchioness with the "other" woman whom her father would be attached to: "your good father", La Voisin understatedly tells her, "appeared to have known the late Marchioness" (86). When Emily thereupon "enquires further" (87) about the "fate" of the Marchioness, La Voisin's refusal to answer suggests the sexual taboo: "enquire no further: it is not for me to lay open the domestic secrets of my lord" (86). La Voisin's blocking her "farther enquiry", which is both a "father" and a "mother" enquiry, ${ }^{13}$ allows for Emily's confusion between the "domestic secrets" of the Marquis and Signora Laurentini and those she suspects between the Marchioness and St Aubert. In fact, the Marchioness, St Aubert's sister, was forced to marry the Marquis despite being in love with someone else, of a lesser fortune. The Marquis himself had a lover (Signora Laurentini) who convinced the Marquis to murder St Aubert's sister. The reader and Emily will not know this until later in the romance, yet throughout the novel, the reader and Emily are led to believe that the Marchioness is St Aubert's lover, and, what is more, her real mother, even her incestuous mother since Emily will think herself to be the daughter of her father and his sister. The epiphanic moment is thus intimately linked to a "recognition" concerning the maternal origin. However, it is in fact linked only to what one thinks one sees, to a "recognition" which turns out to have been none. In that respect the seemingly epiphanic discovery of the miniature portrait is only a false epiphany.

The specificity of the "hollow place" that contains the "bundle of papers" and the "purse of louis" is therefore that it contains not only the father's genitals but also what gives Emily the means to reconstruct her genealogy through another mother, to regenerate herself according to another generation and genealogy. The "hollow place" is thus a womblike symbol: the womb, like the "hollow place" in the closet, is itself an empty space to be filled by the male genitals, just as the "hollow place" is filled by the "purse" Emily discloses. This purse, contained in the "hollow place", is not associated exclusively with the father's genitals. For the purse also contains the "miniature of a - lady". This foetus-like picture was contained in an "ivory case," itself wrapped "paper after paper" in a "small packet", itself contained at the "bottom of the purse". Emily finds the purse harbouring nothing other than the image of the repressed, secret mother, miniaturized as if this "lady" were Emily's infant daughter. Obviously, the "purse" itself is a hoary metaphor of the womb and a metonymy of the mother. A coin purse is traditionally analogical to the uterus, to the womb: "The uterus ... is a tightly sealed

13. Radcliffe frequently puns on "farther" as "father", e.g.: "farther guilt" which in context in The Romance of the Forest is father guilt (209); or places them side by side, "She tried to spare her father from farther view" $(M U, 76)$; or makes the one be the other: "Monsieur, your good father, appeared to have known the late Marchioness' (La Voisin); 'Pray inform me what did happen?' said Emily ...; 'enquire no further: it is not for me to lay open the domestic secrets of my lord" (La Voisin answering) (86). To enquire "further" is to enquire about her "father". 
vessel, similar to a coin purse. ${ }^{14}$ This analogy goes back to Christian doctrine and to Christian theological debates, when the issue was whether the Virgin Mary was divine, thus like what she carried in her purse (the foetus Jesus), or just contiguous with the divine (as a purse is to the money it holds). The eighth-century emperor Constantine V argued against the divinity of Mary by comparing her to a purse containing gold:

Taking in his hand a purse full of gold and showing it to all, he asked, "What is it worth?" They replied that it had great value He then emptied out the gold and asked, "What is it worth now?" They said, "Nothing." "So," said he, "Mary (...) while she carried Christ within herself was to be honored, but after she was delivered she differed in no way from other women." 15

This example taken from Constantine of the Virgin Mary as purse-womb containing the divine, is all the more relevant since Emily will explicitly be compared with both Marys: "Hers was the contour of a Madona, with the sensibility of a Magdalen" (184). The purse containing gold can thus be read not only as a symbol of male generative potential (through money, through semen), but also as a symbol of the female generative matrix.

The "hollow place" thus contains "bundle" (testicles), "purse" (scrotum and womb), the latter containing a "small packet" wrapped by "paper after paper" which, unfolded, reveal the "miniature lady". The condensation of the image of the "purse" and its contents ("coin" images of father, "miniature of a - lady") consists in the fact that it metamorphoses its sex before our eyes. At first it is associated with masculine connotations: indeed, St Aubert at first called the "bundle of papers" a "packet" in the scene where he gives his instructions to Emily: "you will find a packet of written papers" (78). This "purse" is enshrouded in what is connoted as masculine, namely in "paper" ("unfolded paper after paper"), and seems unmistakably male: Emily "kissed some pieces of the coin, and wetted them with her tears" - to follow up the Shakespearean metaphors of "coins" and "purses" as testicles and scrotums. Yet the purse image gives way to that of a womb, female therefore, which contains the female (picture): an "ivory case, containing the miniature of a - lady!” The female, already associated with

14. Auslegung und Beschreibung der Anathomy oder warhaffen abcontersetuin eines inwendigen Corpers des Manns und Weibs, Strasbourg, 1539, quoted in Shell 30.

15. Vitae Nicetae, in Acta Sanctorum, ap. 1, app. 23; quoted in Shell, 34. a "container", is contained within the "ivory case", of which "ivory" suggests female skin, and which is contained within the "container"/purse.

Epiphany as transgressive reading: seeing what ought not to be read If this epiphanic scene in Mysteries of Udolpho thus functions as the manifestation and recognition both of the male/father and of the female/mother, the difference between the appearing of the male and that of the female is that the epiphanic manifestation linked to the father is mainly associated with writing that ought not be read (the papers), whereas the epiphany linked to the mother is associated with visual representation which may be read (the miniature). The "true" epiphany consists in a transgressive act whereas the false epiphany is no transgression.

Everything that was prohibited regarding the papers (and the father) is permitted regarding the miniature lady (and the woman Emily believes to be her real mother). Whereas Emily was under the injunction to burn the papers "without examining them" (78), no Law has been laid down concerning the purse and the miniature: "St Aubert had given no directions concerning this picture ...; she, therefore, thought herself justified in preserving it" (104). The "purse" can thus be "read", which is what Emily is about to do as she "recollect[s] the purse" (lectio from legere, to gather, to read) and she does with the portrait precisely what she was not allowed to do with the papers: she "examines" it. The word "examine" is repeated three times: "she examined it"; "On examining the countenance"; "examining its features" (104). There is therefore no transgression in examining the picture because there had been no right, no droit, concerning it. On the contrary, a law has been laid down concerning the papers. Indeed, St Aubert, the father, is the voice of the law, of Right, which as such is what is absolute, not questionable, inflexibly straight: ${ }^{16}$

"Attend to me now, for the promise you have given particularly relates to what I shall direct. These papers you must burn - and,

16. Reason is associated with what is straight, firm and right (as in the French word droit). The word "directions" in "the directions which St Aubert had given her" contains the word "rectio", or "right". Following the directions of her father is equal to doing what is right, with the "return" of "reason", and with the moral, "reproach". "Reason" "returned; she reproached herself". Reason, following directions, is enacted by localizing verbs that emphasize geometrical angles, and thus straight lines: "she readily found the board ... in an opposite corner"; "she distinguished also the line" Reason is straight and moral (Right), as Laurence Sterne's Tristram Shandy puts it: "This right line"," ", is "the emblem of moral rectitude!" (W.W. Norton edn, 1980, 334). 
solemnly I command you, without examining them' [Radcliffe's emphasis].

Emily's surprise, for a moment, overcame her grief, and she ventured to ask, why this must be? St Aubert replied, that, if it had been right for him to explain his reasons, her late promise would have been unnecessarily exacted (78).

The Right and the Law, spoken by the father, concern the papers but not the picture. The picture can thus be read, not the writing.

Emily, however, sees what she is not allowed to read: after taking out of the closet the "bundle of papers" and the "purse of louis", after seeing the ghost of her father,

her eyes involuntarily settled on the writing of some loose sheets, which lay open; and she was unconscious, that she was transgressing her father's strict injunction, till a sentence of dreadful import awakened her attention and her memory together (103).

"Her eyes" act without her mind, will or consciousness: "she was unconscious". Such mental vacancy is the mode, and the moment, of the epiphany as it takes place at the very moment when Emily, overwhelmed by the apparition of her father's ghost, "sunk almost senseless into a chair" (103). ${ }^{17}$ The epiphanic moment is thus associated with an unconscious and involuntary seeing (as opposed to the conscious reading of the visual representation). This epiphany is a seeing that is resolutely not a reading. There is certainly a "sentence", which reinforces the juridical lexical field, but she does not read it. Rather it - the "sentence" - is the active agent: "a sentence ... awakened her attention". In the overdetermined epiphany of seeing the ghost of her father, of emasculating him, Emily also sees a "sentence" of "dreadful import". This moment of seeing is related to reading not only in a negative way (Emily does not read, she sees) but also in a subversive way: the seeing of the sentence is "d-read-ful", and the word "d-read-ful" had already appeared a few lines

17. Epiphany is momentary: "With a trembling hand she removed them ... paused a moment ... when ... there appeared ... the same countenance in the chair" (103); "her excellent understanding ... yielded, even for a moment, to the reveries of superstition, or rather to those starts of imagination, which deceive the senses into what can be called nothing less than momentary madness" (102); "For a moment, she even doubted, whether [the promise] could justly be obeyed"; "the delusion was momentary" (103). The moment is delusion. Delusion is epiphany. Epiphany is thi moment. earlier to qualify Emily's vision of her father's ghost ("the dreadful but pitiful attack of imagination"). Emily's unconscious reading - her seeing - leads her to see her father's letters out of their context (she only sees "some loose sheets"), and therefore to misrecognize what she sees, just as we can see "read" out of its context in "dreadful". The moment of epiphany is thus a moment of seeing which is not reading, which in fact transgresses and subverts reading.

Emily's seeing is further associated with transgression insofar as, in contrast with the rightfully and justly seen miniature of the lady, the writing was only seen unrightfully and as a transgression of the law of the father. If the transgression is involuntary and unconscious, what she sees affects her so much that it leads her to call into question the rightfulness of the law that she should be obeying: "So powerfully had they [the papers] affected her that she even could not resolve to destroy the papers immediately ... she began to lament her promise to destroy the papers. For a moment she even doubted, whether it could justly be obeyed" (103). The moment of epiphany is not only the moment of an other kind of seeing the text but also that of an other kind of justice, necessitating disobedience and associated not with reason but with imagination, not with the father but with the daughter. Emily, however, promptly returns to reason and obedience. Her "temptation" to disobey is shut down by the logic of Right: "it is not my business to argue, but to obey. Let me hasten to remove the temptation", she says, whereupon she "complete[s] the triumph of integrity over temptation ... and consign[s] the papers to the flames" (103). Whereas the transgression of the law was unconscious, so that unconsciousness is the absence of law and therefore not really transgressive as such, in contrast consciousness itself is consciousness of the law: Emily destroys the papers to avoid "consciousness of irremediable guilt" (103).

The narrator's description of what happens to Emily when she sees without reading suggests a method of reading The Mysteries of Udolpho. Just as Emily's epiphany is described as seeing but not reading words which she will not subsequently be able to erase from her thoughts, this very description can also describe how the reader, looking at the writing but not reading its meaning, may detect or uncover certain words and words within words which she may no longer dismiss from her thoughts, and may no longer dissociate from her reading the page, that is, from the meaning of the explicit words. What the narrator describes is the fact that, in Emily's epiphanic reading, the "word," or "signifier," takes over, becomes more powerful, than the "thought" or "signified." The "word" in its materiality haunts Emily's mind ("the words ... she could not dismiss from her thoughts"). Moreover, her seeing of these words is 
always described as fragmentary, oblique and indirect. In fact it is a "glancing": the expression "her eyes glancing" tells of such oblique, cursory and momentary vision. "Glance" coming from the Old French, glacier, or "to slide". "Her eyes glancing" suggests the instability of such seeing, and the instability about what was perhaps seen. It is also fragmentary because such vision is only a vision of fragmented text: she only sees "the writing of some loose sheets," so that "her eyes" not only glimpse the writing, but only get a glimpse of the text as a whole. Such a "glancing" vision was also already suggested at the beginning of the romance, immediately after Emily's "The Glow-Worm" poem about incest, when the narrator glossed her poem with these lines from James Thomson about unstable, fragmentary vision:

A faint erroneous ray

Glanc'd from th'imperfect surfaces of things,

Flung half an image on the straining eye;

Uncertain if beheld (17).

What is described is thus an oblique kind of seeing, a reading under erasure insofar as it is not a reading (but a seeing) and insofar as it is a transgressive and a fragmentary non-reading. This oblique reading is epiphanic, insofar as the epiphany like this reading is the "sudden recognition" of what is not visibly and tangibly there, hence a vision which appears in the same moment that it disappears, disappears in the moment it appears. 